\title{
Isolation of Arcobacter species and other neglected opportunistic agents from aborted bovine and caprine fetuses
}

\author{
Alessia Di Blasio ${ }^{1}$, Amaranta Traversa ${ }^{1}$, Federica Giacometti ${ }^{2 *}$ (D), Francesco Chiesa ${ }^{3}$, Silvia Piva ${ }^{2}$, Lucia Decastelli ${ }^{1}$, \\ Alessandro Dondo', Silvia Gallina ${ }^{1}$ and Simona Zoppi ${ }^{1}$
}

\begin{abstract}
Background: Infectious abortion in ruminants is a problem in animal husbandry worldwide. It is important to obtain a diagnosis, to make sure that proper control measures can be instituted, but most abortion cases remain without an etiologic diagnosis. This report describes the presence of Arcobacter species and several neglected opportunistic abortifacient agents in ruminant abortion cases showing or not co-infections among at least one of the major recognized protozoal, fungal, bacterial and viral abortifacient agents.

Results: A total of 67 fetuses (55 cattle and 12 goats) and just one placenta (cattle) were considered. Among the most common abortive agents, Neospora caninum (19,4\%), followed by Chlamydophila abortus (4,5\%), Listeria monocytogenes 1/2a (2,98\%), Bovine Viral Diarrhea Virus type 1b (2,98\%), Bovine herpesvirus 4 (2,98\%), and Aspergillus spp. $(2,98 \%)$ were detected. The isolated neglected opportunistic bacteria include Escherichia coli, Acinetobacter Iwoffii, Staphylococcus spp., Streptococcus spp., Streptococcus uberis, Streptococcus suis, Trueperella pyogenes, Mannheimia haemolytica, Bacillus cereus and Nocardia spp. Other bacterial species, not associated with abortion by literature, but described as causes of diseases occurring sporadically both in humans and animals, were also detected. Three Arcobacter strains, namely two A. skirrowii and one A. cryaerophilus, were isolated from 3 bovine aborted fetuses, and $A$. butzleri was isolated from the placenta.
\end{abstract}

Conclusions: A not negligible isolation of Arcobacter species and other neglected abortifacient agents has to be mentioned, with prevalences that seem to be emerging and replacing or co-placing the major infectious players in bovine and caprine reproductive failure due to abortion disease, even if further studies investigating the aetiological power and transmission routes are needed in order to define the role of these microrganisms in ruminant abortion.

Keywords: Arcobacter species, Opportunistic emerging pathogens, Aborted fetuses, Co-infections

\section{Background}

Infectious abortion in ruminants is a problem in animal husbandry worldwide, and abortion in cattle, with an estimated rate from 2 to $5 \%$, is widely acknowledged to cause considerable economic losses and, despite extensive histopathologic, microbiologic, and molecular investigations, most bovine abortion cases remain without an etiologic diagnosis [1]. The major infectious agents involved in ruminant abortion are Neospora caninum, Bovine pestiviruses,

\footnotetext{
*Correspondence: federica.giacometti3@unibo.it

${ }^{2}$ Department of Veterinary Medical Sciences, University of Bologna, Via Tolara di Sopra 50, 40064, Ozzano Emilia, Bologna, Italy

Full list of author information is available at the end of the article
}

Bovine herpesvirus 1 and 4, Parainfluenza virus type 3, Brucella spp., Chlamydophila abortus, Coxiella burnetii, Campylobacter fetus, Salmonella sp., Listeria spp., and Aspergillus spp.. However, most bacterial causes of abortion are opportunistic pathogens. These organisms are not infectious, and are common inhabitants of the host or its environment and might include Arcanobacterium pyogenes and Bacillus spp. followed by Escherichia coli, Histophilus somni, Pasteurella spp., Staphylococcus spp., Streptococcus spp., and any other bacteria that can find their way into the bloodstream can cause sporadic abortion [2]. Moreover Arcobacter species have been reported to be involved in animals abortion [3, 4].

(c) The Author(s). 2019 Open Access This article is distributed under the terms of the Creative Commons Attribution 4.0 International License (http://creativecommons.org/licenses/by/4.0/), which permits unrestricted use, distribution, and 
The first report of bacteria now known as arcobacters was originally described by Ellis et al. (1977) [5] as an isolation of "Spirillum/Vibrio-like organisms" from placenta and internal organs of bovine fetuses; these microorganisms were initially assigned to the genus Vibrio, but, considering their failure in fermenting carbohydrates, they were subsequently transferred into the genus Campylobacter as an atypical and heterogeneous group of aerotolerant campylobacters [6]. In 1991, the genus Arcobacter was created by Vandamme and Colleagues to accommodate these two atypical campylobacters, Campylobacter nitrofigilis [7] and Campylobacter cryaerophila [6] and, in 1992, the genus was enlarged with the reclassification of Campylobacter butzleri, isolated from human stools but also from animals [8], as Arcobacter butzleri, and with the inclusion of a new species, Arcobacter skirrowii, isolated predominantly from preputial fluids of bulls or from bovine, porcine, and ovine aborted fetuses, as well as from diarrhoeic feces [9]. Hitherto, a total of 27 Arcobacter species have been described in a wide variety of ecological niches and from various hosts and environments, mainly described from water-related environments and shellfish [10]. Arcobacters are considered emerging bacterial zoonotic agents: A. butzleri, A. cryaerophilus and A. skirrowii are the species most commonly described in clinical conditions, namely associated with human and animal disease. Furthermore, as the Arcobacter organisms are commonly isolated from fecal samples of healthy animals and humans, and they are unable to satisfy the Koch's postulate, their pathology and pathogenicity are under dispute [11]. In animals, arcobacters may play a role in animal reproductive disorders, such as infertility and late-term abortions in cattle, pigs, sheep [12], equine and alpaca [13]. In literature, the species involved in abortions are A. cryaerophilus, A. skirrowii, A. butzleri, A. thereius [3] and $A$. porcinus [4]. However, since the first isolation, arcobacters were reported in bovine abortions only in three cases [14-16] and, differently from pigs, no studies in literature have clearly identified the role of the genus Arcobacter as abortifacient pathogen and as causative agent of disease in cattle.

This report is to describe the isolation of Arcobacter species, long time since the last description in literature, and other neglected opportunistic abortifacient agents from the abomasum's content of aborted fetuses both of cattle and small ruminants coming from a passive Bovine Brucellosis (BB) Surveillance National plan performed in Piedmont, an officially BB-free Italian region. The aim of this study is presenting important and inspiring data on the isolation of Arcobacter species and other bacterial agents that seem to be emerging and replacing or co-placing the major infectious players in bovine reproductive failure due to abortion disease.

\section{Results}

A total of 67 fetuses ( $n=55$ cattle and $n=12$ goats) and just one placenta (cattle) were collected and analyzed. The absence of gross lesions at necropsy was reported in almost all $(n=64)$ the fetuses. The findings of the diagnostic approach showed that: i) 25 fetuses $(37,3 \%)$ were negative for any protozoal, fungal, bacterial and viral agents investigated; ii) 22 fetuses (32,8\%), 19 bovine and 3 caprine, were positive only to routine bacteriological exam on blood agar plates (Table 1); iii) 10 fetuses (14, 9\%), 8 bovine and 2 caprine, showed a single positivity for only one among the investigated pathogens, namely $N$. caninum $(\mathrm{n}=6), C$. abortus $(n=2), L$. monocytogenes 1/2a $(n=1)$ and Bovine Viral Diarrhea Virus (BVDV) type $1 \mathrm{~b}(\mathrm{n}=1)$; iv) 10 fetuses $(14,9 \%)$ showed different coinfections among recognized protozoal, fungal, bacterial and viral abortifacient agents, and, three Arcobacter strains, two A. skirrowii and one A. cryaerophilus, were isolated from 3 among these 10 bovine aborted fetuses (Table 2). Moreover, a strain of A. butzleri was isolated from the placenta, in purity. Among the overall investigated Arcobacter virulence genes, only cia $\mathrm{B}$ and $m v i \mathrm{~N}$ were detected and were present in all the isolates.

\section{Discussion}

Establishing a definitive cause of bovine abortion is a challenging problem faced by veterinary practitioners and diagnosticians [17] and the knowledge of the most common causes of bovine abortion is useful to set up interventions able to mitigate future fetal loss in the herd. A not negligible percentage of fetuses with negative results for infectious abortion agents and the almost overall absence of anatomopathological lesions have to be mentioned in this report, in line with the literature, and highlighting, once again, as these scenarios can interfere with the recovery of causative agents.

Among the 42 fetuses in which an infectious agent was identified, bacterial agents, followed by viral, protozoal and fungal agents were identified. The most common abortive agent detected resulted $N$. caninum ( $n=13,19,4 \%)$, followed by $C$. abortus $(n=3,4,5 \%), L$. monocytogenes $1 / 2 \mathrm{a}(n=2,2,98 \%)$, BVDV type $1 \mathrm{~b}(\mathrm{n}=2$, 2,98\%), Bovine herpesvirus $4(\mathrm{n}=2,2,98 \%)$, and Aspergillus spp. ( $\mathrm{n}=2,2,98 \%)$. However, several abortion cases with multiple possible etiologies were detected, both in the 10 cases with co-infections among the well-recognized abortifacient agents (Table 2) as well as in the 22 cases with positive bacterial cultures on blood agar plates that are not primary abortifacient agents (Table 1). In fact, whereas Neospora spp., C. abortus, L. monocytogenes, BVDV and BoHV4 are recognized as abortifacient agents, the other isolated bacterial species are usually considered pathogenic or opportunistic or commensal or environmental bacteria. Recent studies 
Table 1 Positive bacteriological findings of the routine exam on blood agar for abortion cases

\begin{tabular}{|c|c|c|}
\hline Animal species & Necropsy & Bacteriology \\
\hline Caprine & No Visible Lesion & Staphylococcus equorum, Aerococcus viridans \\
\hline Caprine & No Visible Lesion & Staphylococcus equorum, Aerococcus viridans \\
\hline Caprine & No Visible Lesion & Staphylococcus equorum \\
\hline Bovine & $\begin{array}{l}\text { Congenital goiter and } \\
\text { heart defect }\end{array}$ & $\begin{array}{l}\text { Acinetobacter Iwoffii, Staphylococcus sciuri, } \\
\text { Staphylococcus lentus, Escherichia coli }\end{array}$ \\
\hline Bovine & $\begin{array}{l}\text { Gelatinous subcutaneous } \\
\text { oedema, hepatomegaly }\end{array}$ & Trueperella pyogenes \\
\hline Bovine & Generalized oedema & Escherichia coli, Streptococcus alactolyticus \\
\hline Bovine & No Visible Lesion & Streptococcus suis \\
\hline Bovine & No Visible Lesion & Escherichia coli \\
\hline Bovine & No Visible Lesion & Escherichia coli \\
\hline Bovine & No Visible Lesion & $\begin{array}{l}\text { Corynebacterium spp., Staphylococcus lentus, } \\
\text { Pseudomonas spp. }\end{array}$ \\
\hline Bovine & No Visible Lesion & Streptococcus uberis \\
\hline Bovine & No Visible Lesion & Bacillus cereus, Burkholderia cepacia \\
\hline Bovine & No Visible Lesion & Escherichia coli \\
\hline Bovine & No Visible Lesion & Pseudomonas spp. \\
\hline Bovine & No Visible Lesion & $\begin{array}{l}\text { Aerococcus viridans, weeksella viros/Bergeyella } \\
\text { zoohelcum }\end{array}$ \\
\hline Bovine & No Visible Lesion & Pantoea ananatis \\
\hline Bovine & No Visible Lesion & $\begin{array}{l}\text { Acinetobacter Iwoffii, Corynebacterium } \\
\text { glutamicum }\end{array}$ \\
\hline Bovine & No Visible Lesion & Nocardia spp., Sphingomonas paucimobilis \\
\hline Bovine & No Visible Lesion & Escherichia coli \\
\hline Bovine & No Visible Lesion & Enteroccus faecium \\
\hline Bovine & No Visible Lesion & Acinetobacter Iwoffii, Streptococcus spp. \\
\hline Bovine & No Visible Lesion & Escherichia coli \\
\hline
\end{tabular}

Abortion cases with positive bacteriological findings on the routine exam on blood agar with description of the observed anatomopathological lesions, animal species and bacterial species isolated

Table 2 Abortion cases showing co-infections among at least one of the major recognized protozoal, fungal, bacterial and viral abortifacient agents

\begin{tabular}{|c|c|c|c|c|c|c|c|}
\hline $\begin{array}{l}\text { Animal } \\
\text { Species }\end{array}$ & Bacteriology \& Micology & N. caninum & C. abortus & Arcobacter spp. & BOHV4 & BVDV & Listeria spp. \\
\hline Bovine & NEG & POS & NEG & NEG & POS & NEG & NEG \\
\hline Bovine & $\begin{array}{l}\text { Acinetobacter Iwoffii, } \\
\text { Aerococcus viridans } \\
\text { Aspergillus spp. }\end{array}$ & POS & NEG & A. skirrowii & NEG & NEG & NEG \\
\hline Bovine & NEG & NEG & NEG & A. cryaerophilus & NEG & BVD 1b & NEG \\
\hline Bovine & Acinetobacter Iwoffii, Escherichia coli & POS & NEG & NEG & NEG & NEG & NEG \\
\hline Bovine & Aspergillus spp. & NEG & NEG & NEG & NEG & NEG & L. innocua \\
\hline Bovine & Escherichia coli & POS & NEG & NEG & NEG & NEG & NEG \\
\hline Bovine & Mannheimia haemolytica & POS & NEG & NEG & NEG & NEG & NEG \\
\hline Bovine & NEG & POS & NEG & NEG & POS & NEG & NEG \\
\hline Bovine & NEG & POS & NEG & A. skirrowii & NEG & NEG & NEG \\
\hline Caprine & Staphylococcus epidermidis, Staphylococcus equorum & NEG & POS & NEG & NEG & NEG & NEG \\
\hline
\end{tabular}

POS: positive; NEG: negative 
indicate that uterus is not sterile during pregnancy and potentially pathogenic bacteria can be present in the placenta of term pregnancies without causing abortion or inflammation [18], and therefore, the bacterial species not described as primary abortifacient agents could play a role as opportunistic pathogens, components of the uterine microbiota, or contaminants of the post-abortive phase. In our study, several abortion cases contained different bacterial species, recovered from the routine bacteriological exam on blood agar plates, that could be classified as possible abortive bacterial agents, given they were previously reported by literature as opportunistic abortive bacteria, namely Escherichia coli $(n=9)$, Acinetobacter lwoffii $(n=5)$, Staphylococcus spp. $(\mathrm{n}=5)$, Streptococcus spp. $(n=1)$, S. uberis $(\mathrm{n}=1)$, S. suis $(\mathrm{n}=1)$, Trueperella pyogenes $(\mathrm{n}=1)$, Mannheimia haemolytica $(\mathrm{n}=1)$, Bacillus cereus $(\mathrm{n}=1)$ and Nocardia spp. $(\mathrm{n}=1)[2,17,19-25]$. On the contrary, other bacterial species isolated in the present study (Staphylococcus sciuri, Staphylococcus equorum, Staphylococcus epidermidis, Streptococcus suis, Streptococcus alactolyticus, Corynebacterium spp., Burkholderia cepacia, Weeksella viros/Bergeyella zoohelcum, Pantoea ananati, Sphingomonas paucimobilis), have never been associated with abortion even if they have been described as causes of diseases occurring sporadically both in humans and animals [26-36]. As previously suggested by Vidal et al. (2017) mixed infections may play an underestimated role in ruminant abortions. In fact, it is often difficult to assess the presence of potentially infectious bacteria in cultures, particularly in cases where rare opportunistic agents are identified, as they tend to be overlooked as contaminants, but, similarly, complementary pathological analyses are needed to avoid overinterpretation of mere detection of the opportunistic pathogens [22].

Regarding the association of Arcobacter spp. with infertility and abortion in livestock animals, it has been reported worldwide but its role in abortions was investigated predominantly in pigs, in which the transmission of Arcobacter species was demonstrated from carrying sows to their offspring, both vertically and horizontally [37]. On and Colleagues in 2002 [38], reported, in one hand, a high Arcobacter prevalence in Danish pig abortions, in cases in which no established abortifacient agent is detected, but in the other, they recommend that other studies are needed to define the role of each Arcobacter species, especially where co-infections with other agents are present, suggesting that some Arcobacter strains play a primary role in abortion while others may be opportunistic pathogens colonizing the fetus.

In our report, Arcobacter species resulted the most isolated bacteria in bovine fetuses among the 10 cases with co-infections, with $N$. caninum in two cases and BVD type $1 \mathrm{~b}$ in one other case; in addition, in two of these cases $A$. skirrowii and A. cryaerophilus resulted the only bacterial species isolated. To note that Arcobacter species were never isolated from blood agar plates performed during routine microbiological exam with incubation temperature of $37^{\circ} \mathrm{C}$; in case of other microbial contamination, Arcobacter species are masked by the other populations that overgrow on plates, or the higher incubation temperature could hinder the Arcobacter growth, and, therefore, a selective bacteriological approach should be the better choice in order to evaluate the presence of the genus Arcobacter. The true incidence and data on Arcobacter species on animal abortion are presumed to be underreported and probably greatly underestimated.

This report revived the presence of Arcobacter spp. in bovine abortion and described as A. cryaerophilus and A. skirrowii could have had an active but not exclusive role in the observed fetal deaths and, consequently, in the observed abortion cases. Differently from what observed in sows by On et al. (2002) [38], the isolation of A. cryaerophilus and A. skirrowii was reported in all the described cases in addition to other organisms frequently associated with bovine abortion ( $N$. caninum and BVDV), and therefore, authors supposed an opportunistic role, if there was, or at least superinfection of Arcobacter spp.. A synergic effect could have occurred on the pathogenesis of the abortion in which several determinants have been explicated their pathogenicity: on the basis of the recovery of A. cryaerophilus and A. skirrowii in the abomasum's content, it is possible to hypothesize an exceeding of the placental barrier, thanks to the injurious or immunosuppressive state induced by other pathogens ( $N$. caninum and BVDV), otherwise, since Arcobacter species have been isolated from several environments and hosts [39, 40], an ascending infection by vaginal pathway or a post-fetal ascendant invasion by Arcobacter spp. could also be hypothesized. The isolation of A. butzleri in the only one placenta submitted to the laboratory immediately after its expulsion, has to be described, even if no specific conclusions could be extrapolated. Collection and submission of the placenta should be recommended, if it can be sampled, because it is equally important and could contribute with the entire fetus to abortion diagnosis, but a whole, intact placenta is often rarely received [2], as confirmed by our report.

In our study, no carcasses showed gross lesions, suggesting an indirect action of pathogens on the fetus by impairment of the maternal-fetal circulation (N. caninum) or the mother's immune system failure (BVDV) [2]. The breakable conservation of abortion products leads often to receive specimens in poor condition not suitable for histopathology purposes, and, consequently, a lack of data about the presence and the type of microscopic lesions could limit the definition of the role of each determinant involved in abortion cases. 


\section{Conclusions}

Although $N$. caninum resulted the most common agent of bovine abortions, demonstrating a consistent presence of the organism in cattle abortion cases and, therefore confirming in line with literature that it is still a cattle problem, a not negligible isolation of Arcobacter species has to be mentioned, with prevalence in line with the major abortifacient agents, as well as the isolation of other opportunistic, commensal or environmental bacteria, even if with lower occurrence levels. The frequent isolation of these bacteria should be taken into account in order to assess if the once-major abortion players could be or are being replaced by an increase in these opportunistic pathogens that are identified as possible abortive agents but that remain in the dark zone of knowledge and that seem to be emerging and needing immediate attention. Further studies are needed in order to both identify these emerging opportunistic bacteria, whose incidence in ruminant abortion is likely underestimated, and investigate the transmission routes and the specific role of Arcobacter in bovine abortion.

\section{Methods}

Aborted fetuses coming from a passive BB Surveillance plan in the Piedmont region, in Italy, were included in this report. All abortion products, collected from bovine and caprine herds between October 2017 to July 2018 in the area covered by the Istituto Zooprofilattico Sperimentale del Piemonte, Liguria e Valle d'Aosta (IZSPLV), that includes three Italian regions (Piedmont, Liguria, and the Aosta Valley) of the Northwest Italy, were received at
IZSPLV laboratory. Samples and analyses included in the present study were performed in accordance with current Regulation concerning of Maintenance of Bovine Brucellosis free Health Status (Directive 97/12/CE, adopted by Italian Law 196/199). Firstly, the carcasses were submitted to necropsy and then followed the application of the routine diagnostic protocol for the detection of the major infectious agents of abortion, namely Salmonella sp., Listeria spp., Brucella spp., C. fetus, C. abortus, C. burnetii, N. caninum, Bovine pestiviruses, Bovine herpesvirus 1 and 4, Parainfluenza virus type 3, fungi and yeasts. See Table 3 for more details and references [41-47]. In addition, a routine bacteriological examination on blood agar plates (Columbia agar, Liofilchem s.r.l., Roseto degli Abruzzi, Italy) incubated at $37^{\circ} \mathrm{C}$ was performed for each fetus sample considered in the study from the abomasum's content. This protocol has been extended with a selective bacteriological exam for the isolation of Arcobacter spp. [48]. In detail, $1 \mathrm{ml}$ of this specimen was enriched in Preston broth (Microbiol \& C. snc, Cagliari, Italy) under Carbon Dioxide-enriched atmosphere condition at $30^{\circ} \mathrm{C}$; every $24 \mathrm{~h}$ for the following 3 days, broth culture were subcultured, under the same conditions, on Charcoal Cefoperazone Deoxycholate Agar (CCDA; Oxoid, Milan, Italy) added with CAT supplement, cefoperazone (8 mg l-1), amphotericin (10 mg l-1), teicoplanin (4 mg l-1) (Oxoid, Milan, Italy). CAT-CCDA plates were observed for 5 days and on suspected colonies Gram staining was performed. According to the protocols described by Douidah $(2010,2012)[49,50]$, the strains identified morphologically as Arcobacter spp. were processed with two end-point multiplex PCR in order to identify the species and to detect

Table 3 Diagnostic protocol applied on the considered aborted fetuses

\begin{tabular}{|c|c|c|c|}
\hline Pathogen & Matrix & Test and references & Animal species \\
\hline Bovine herpesvirus 1 & Lung & FAT $^{\mathrm{a}}, \mathrm{PCR}[41]$ & Cattle \\
\hline Bovine herpesvirus 4 & Lung & $F A T^{a}$ & Cattle \\
\hline Pestiviruses & Spleen & $\mathrm{ELISA}^{\mathrm{b}}, \mathrm{PCR}[42]$ & Cattle; Small Ruminants \\
\hline Brucella spp. & $\begin{array}{l}\text { Content of abomasum } \\
\text { Pool of organs }\end{array}$ & Bacteriological [43] & Cattle; Small Ruminants \\
\hline Campylobacter fetus & $\begin{array}{l}\text { Content of abomasum } \\
\text { Liver }\end{array}$ & Bacteriological [44], PCR [41] & Cattle; Small Ruminants \\
\hline Chlamydophila abortus & Liver & PCR [41] & Small Ruminants \\
\hline Coxiella burnetii & CNS, Liver, Kidney, Lung & PCR [41] & Cattle; Small Ruminants \\
\hline Fungi and yeasts & Content of abomasum & Bacteriological [45] & Cattle; Small Ruminants \\
\hline Listeria spp. & Content of abomasum & Bacteriological [46] & Cattle; Small Ruminants \\
\hline Neospora caninum & CNS, Liver, Kidney, Lung & PCR [41] & Cattle \\
\hline Parainfluenza virus type 3 & Lung & $\mathrm{FAT}^{\mathrm{a}}$ & Cattle \\
\hline Salmonella sp. & Liver & Bacteriological [47] & Cattle; Small Ruminants \\
\hline
\end{tabular}

Diagnostic protocol currently applied on the considered aborted fetuses in the IZSPLV laboratory with indication, for each pathogen, of the considered matrix and test used for its isolation and or detection and the considered animal species. CNS: central nervous system; ${ }^{\mathrm{a}} \mathrm{FAT}$ : fluorescence antibody testing; internal method

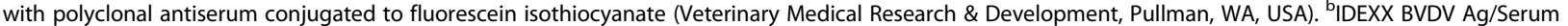
Plus, Switzerland 
virulence genes $(c a d \mathrm{~F}, p l d \mathrm{~A}, t l y \mathrm{~A}, c i a \mathrm{~B}, \operatorname{rrg} \mathrm{A}, h e c \mathrm{~A}, m v i \mathrm{~N}$, cj1349 and hecB). All the considered strains were identified or confirmed using Vitek-MS (bioMerieux Italia, Florence, Italy). The reference strains, $A$. butzleri DSM 8739TM, $A$. cryaerophilus DSM 7289TM, and an A. skirrowii field strain, confirmed by Sanger sequencing, were used as positive control.

\section{Abbreviations}

BB: Bovine Brucellosis; BVDV: Bovine Viral Diarrhea Virus; IZSPLV: Istituto Zooprofilattico Sperimentale del Piemonte, Liguria e Valle d'Aosta

\section{Acknowledgements}

We thank Maria Angelillo for her excellent technical support.

\section{Authors' contributions}

LD and SG conceived the study; ADB, SZ, SG and AT were responsible for the study coordination, sample collection, data analyses and drafting the manuscript: $A D$ and SZ were responsible for the pathological and further investigations concerning of the applied differential diagnosis protocol; SG, $A T, A D B$ and $F C$ were responsible for all the analyses; FG, SZ and ADB wrote the manuscript; FG, SP and ADB edited the manuscript; LD and SG provided funding. All authors have read and approved the manuscript.

\section{Funding}

This research project was funded by the Italian Ministry of Health (Project $n$ IZS PLV 05/14 RC). the funders had no role in study design, data collection and analysis, decision to publish, or preparation of the manuscript.

\section{Availability of data and materials}

The datasets generated during the current study are not publicly available. However, the data can be available from Authors upon request (please contact Alessia Di Blasio, Alessia.DiBlasio@izsto.it).

\section{Ethics approval and consent to participate}

All samples included in this study were received as routine diagnostic submissions for the screening of abortions as prescribed by law. Samples and analyses included in the present study were performed in accordance with current Regulation concerning of Maintenance of Bovine Brucellosis free Health Status (Directive 97/12/CE, adopted by Italian Law 196/199). No experimental protocols were applied; consequently, the need for ethics approval is deemed unnecessary by the IRB of IZSPLV, because the activities described in this study are not part of the pertinence field of current Regulation on the protection of animals used for scientific purposes (Directive 2010/63/UE, adopted by Italian Law 26/2014).

\section{Consent for publication}

Not applicable.

\section{Competing interests}

The authors declare that they have no competing interests.

\section{Author details}

'Istituto Zooprofilattico Sperimentale del Piemonte, Liguria e Valle d'Aosta, Via Bologna 148, 10154 Torino, Italy. ${ }^{2}$ Department of Veterinary Medical Sciences, University of Bologna, Via Tolara di Sopra 50, 40064, Ozzano Emilia, Bologna, Italy. ${ }^{3}$ Department of Veterinary Medical Sciences, University of Torino, Largo Paolo Braccini 2, Grugliasco, 10095 Torino, Italy.

\section{Received: 22 February 2019 Accepted: 16 July 2019}

Published online: 24 July 2019

\section{References}

1. Botta C, Pellegrini G, Hässig M, Pesch T, Prähauser B, Wunderlin S, Guscetti F, Schneeberger M, Schmitt S, Basso W, Hilbe M, Schuler G, Borel N. Bovine fetal placenta during pregnancy and the postpartum period. Vet Pathol. 2018:I-I.

2. Holler LD. Ruminant abortion diagnostics. Vet Clin Food Anim. 2012;28:407-18.
3. Houf K, On SL, Coenye T, Debruyne L, De Smet S, Vandamme P. Arcobacter thereius sp. nov., isolated from pigs and ducks. Int I Syst Evol Microbiol. 2009;59:2599-604

4. Figueras MJ, Pérez-Cataluña A, Salas-Massó N, Levican A, Collado L. 'Arcobacter porcinus' sp. nov., a novel Arcobacter species uncovered by Arcobacter thereius. New Microbes New Infect. 2017;15:104-6.

5. Ellis WA, Neill SD, O'Brien JJ, Ferguson HW, Hanna J. Isolation of Spirillum/ Vibrio-like organisms from bovine fetuses. Vet Rec. 1977;100:451-2.

6. Neill SD, Cambell JN, O'brien JJ, Weatherup STC, Ellis WA. Taxonomic position of Campylobacter cryaerophila sp. nov. Int I Systemat Bacteriol. 1985;35:342-56.

7. McClung CR, Patriquin DG, Davis RE. Campylobacter nitrofigilis sp. nov., a nitrogen-fixing bacterium associated with roots of Spartina alternijlora. Loisel Int J Syst. Bacteriol. 1983;33:605-12.

8. Kiehlbauch JA, Brenner DJ, Nicholson MA, Baker CN, Patton CM, Steigerwalt AG, Wachsmuth IK. Campylobacter butzleri sp. novo isolated from humans and animals with diarrheal illness. J Clin Microbiol. 1991;29:376-85.

9. Vandamme P, Vancanneyt M, Pot B, Mels L, Hoste B, Dewettinck D, Vlaes L, van den Borre C, Higgins R, Hommez J, Kersters K, Butzler JP, Goossenens H. Polyphasic taxonomic study of the emended genus Arcobacter with Arcobacter butzleri comb. nov. and Arcobacter skirrowii sp. nov., an aerotolerant bacterium isolated from veterinary specimens. Int J Syst Bacteriol. 1992;42:344-56.

10. Pérez-Cataluña A, Salas-Massó N, Diéguez AL, Balboa S, Lema A, Romalde JL, Figueras MJ. Revisiting the taxonomy of the genus Arcobacter: getting order from the chaos. Front Microbiol. 2018;9:2077.

11. Ramees TP, Dhama K, Karthik K, Rathore RS, Kumar A, Saminathan M, Tiwari $R$, Malik YS, Singh RK. Arcobacter: an emerging food-borne zoonotic pathogen, its public health concerns and advances in diagnosis and control - a comprehensive review. Vet Q. 2017;37(1):136-61.

12. Ferreira $\mathrm{S}$, Queiroz JA, Oleastro $M$, Domingues $F C$. Insights in the pathogenesis and resistance of Arcobacter: a review. Crit Rev Microbiol. 2016:42(3):364-83.

13. Wesley IV, Schroeder-Tucker L. Recovery of Arcobacter spp. from non livestock species. J Zoo Wild Med. 2011:42(3):508-12.

14. Higgins R, Degre R. Isolation of spirillum-like organisms from pig and bovine fetuses. Vet Rec. 1979:104:262-3.

15. Fernandez H, Rojas MV, Gajardo T. Primer aislamiento de Arcobacter cryaerophylus a partire de un aborto bovino en Chile. Arch Med Vet. 1995:27:111-4

16. Parvanta MP. Campylobacter cryaerophila and Campylobacter fetus subspecies venerealis as a cause of serial abortions in two cattle herds in North-Rhine-Westfalia. Tieraruliche Umschau. 1999;54:364-71.

17. Clothier $\mathrm{K}$, Anderson M. Evaluation of bovine abortion cases and tissue suitability for identification of infectious agents in California diagnostic laboratory cases from 2007 to 2012. Theriogenology. 2016;85:933-8.

18. Karstrup CC, Klitgaard K, Jensen TK, Agerholm JS, Pedersen HG. Presence of bacteria in the endometrium and placentomes of pregnant Cows. Theriogenology. 99:41-7.

19. Schuh J and Weinstock D (1985) Bovine abortion caused by Bacillus cereus. J am vet med Assoc. 2017;187:1047-1048.

20. Reitt K, Hilbe M, Voegtlin A, Corboz L, Haessig M, Pospischil A. Aetiology of bovine abortion in Switzerland from 1986 to 1995 - a retrospective study with emphasis on detection of Neospora caninum and Toxoplasma gondii by PCR. J Vet Med A. 2007;54:15-22.

21. Parthiban S, Malmarugan S, Murugan MS, Johnson Rajeswa J, Pothiappan P. Review on emerging and reemerging microbial causes in bovine abortion. Int J Food Sci Nutr. 2015:4(4-1):1-6.

22. Vidal S, Kegler K, Posthaus H, Perreten V, Rodriguez-Campos S. Amplicon sequencing of bacterial microbiota in abortion material from cattle. Vet Res. 2017:48:64.

23. Vidal S, Brand W, Dettwiler M, Abril C, Bressan J, Greub G, Frey CF, Perreten V, Rodriguez-Campos S. Limited added value of fungal ITS amplicon sequencing in the study of bovine abortion. Heliyon. 2018; 4(11):e00915.

24. Wareth G, El-Diasty M, Melzer F, Murugaiyan J, Abdulmawjood A, Sprague Lisa D, Neubauer H. Trueperella pyogenes and Brucella abortus coinfection in a dog and a cat on a dairy farm in Egypt with recurrent cases of mastitis and abortion. Hindawi Vet Med Int. 2018:11:4.

25. Reichel MP, Wahl Lloyd C, Fraser I. Review of diagnostic procedures and approaches to infectious causes of reproductive failures of cattle in Australia and New Zealand. Front Vet Sci. 2018;5:222.

26. De Visscher A, Supre K, Haesebrouck F, Zadoks Ruth N, Veerle P, Van Coillie E, Piepers S, De Vliegher S. Further evidence for the existence of environmental and host-associated species of coagulase-negative staphylococci in dairy cattle. Vet Microbiol. 2014;172:466-74. 
27. Segura M, Fittipaldi N, Calzas C, Gottschalk M. Critical Streptococcus suis virulence factors: are they all really critical? Trends Microbiol. 2017;25(7):585-99.

28. Okwumabua O, Peterson H, Hsu H, Bochsler P, Behr M. Isolation and partial chara terization of Streptococcus suis from clinical cases in cattle. J Vet Diagn Investig. 2017;29(2):160-8.

29. Almeida P, Railsback J, Gleason JB. A rare case of Streptococcus alactolyticus infective endocarditis complicated by septic emboli and mycotic left middle cerebral artery aneurysm. Case Rep Infect Dis. 2016;9081352.

30. Hahne J, Kloster T, Rathmann S, Weber M, Lipski A. Isolation and characterization of Corynebacterium spp. from bulk tank raw cow's milk of different dairy farms in Germany. Plos One. 2018;13(4):e0194365.

31. Pradenas GA, Ross BR, Torres AG. Burkholderia cepacia Complex Vaccines: Where Do We Go from here? Vaccines. 2016:4:10.

32. Cain CL, Cole SD, Charles WB, Canfield MS, Mauldin EA. Clinical and histopathological features of Burkholderia cepacia complex dermatitis in dogs: a series of four cases. Vet Dermatol. 2018;29:457-e156.

33. Pan $Z, M a Y, M a ~ J$, Dong $W, Y a o ~ H$. Acute meningitis of piglets and mice caused by co-infected with Streptococcus suis and Aerococcus viridans. Microb Pathog. 2017;106:60-4.

34. Chen Y, Kang L, Lu A, Penghao G, Huang H, Wu Z, Liu M. Bacteremia caused by Bergeyella zoohelcum in an infective endocarditis patient: case report and review of literature. BMC Infectious Dis. 2017;17:271.

35. Weller-Stuart T, De Maayer P, Coutinho T. Pantoea ananatis: genomic insights into a versatile pathogen. Mol Plantpathol. 2017;18(9):1191-8.

36. El Beaino M, Fares J, Malek A, Hachem R. Sphingomonas paucimobilisrelated bone and soft-tissue infections: a systematic review. Int J Infect Dis. 2018;77:68-73.

37. Ho TKH, Lipman LJA, van der Graaf-van Bloois L, van Bergen M, Gaastra W. Potential routes of acquisition of Arcobacter species by piglets. Vet Microbiol. 2006:16:123-33.

38. On SL, Jensen TK, Bille-Hansen V, Jorsal SE, Vandamme P. Prevalence and diversity of Arcobacter spp. isolated from the internal organs of spontaneous porcine abortions in Denmark. Vet Microbiol. 2002;85:159-67.

39. Collado L, Figueras MJ. Taxonomy, epidemiology, and clinical relevance of the genus Arcobacter. Cli Microbiol Rev. 2011;24(1):174-92.

40. Giacometti F, Lucchi A, Di Francesco A, Delogu M, Grilli E, Guarniero I, Stancampiano L, Manfreda G, Merialdi G, Serraino A. Arcobacter butzleri, Arcobacter cryaerophilus, and Arcobacter skirrowii circulation in a dairy farm and sources of milk contamination. Appl Environ Microbiol. 2015; 81(15):5055-63.

41. Tramuta C, Lacerenza D, Zoppi S, Goria M, Dondo A, Ferroglio E, Nebbia P, Rosati S. Development of a set of multiplex standard polymerase chain reaction assays for the iden- tification of infectious agents from aborted bovine clinical samples. J Vet Diagn Invest. 201123(4):657-64.

42. Peletto S, Caruso C, Cerutti F, Modesto P, Zoppi S, Dondo A, Acutis PL, Masoero L. A new genotype of border disease virus with implications for molecular diagnostics. Arch Virol. 2016:161(2):471-7.

43. World Organization for Animal Health (OIE). Manual of diagnostic tests and vaccines for terrestrial animals, 3.1.4. 2016. http://www.oie.int/fileadmin/ Home/eng/Health_standards/tahm/3.01.04_BRUCELLOSIS.pdf. Accessed 15 July 2019

44. World Organization for Animal Health (OIE). Manual of diagnostic tests and vaccines for terrestrial animals, 3.4.4. 2017. http://www.oie. int/fileadmin/Home/eng/Health_standards/tahm/3.04.04_BGC.pdf. Accessed 15 July 2019.

45. Kirkbride CA. Mycotic abortion. Theriogenology. 1976;5(3):139-49.

46. World Organization for Animal Health (OIE) Manual of diagnostic tests and vaccines for terrestrial animals, 3.9.6. 2014. http://www.oie.int/fileadmin/ Home/eng/Health_standards/tahm/3.09.06_LISTERIA_MONO.pdf. Accessed 15 July 2019.

47. World Organization for Animal Health (OIE). Manual of diagnostic tests and vaccines for terrestrial animals, 3.9.8. 2016. http://www.oie.int/fileadmin/ Home/eng/Health_standards/tahm/3.09.08_SALMONELLOSIS.pdf. Accessed 15 July 2019.

48. Kemp R, Leatherbarrow AJ, Williams NJ, Hart CA, Clough HE, Turner J, Wright EJ, French NP. Prevalence and genetic diversity of Campylobacter spp. in environmental water samples from a 100-squarekilometer predominantly dairy farming area. Appl Environ Microbiol. 2005;71:1876-82.
49. Douidah L, De Zutter L, Vandamme P, Houf K. Identification of five human and mammal associated Arcobacter species by a novel Mul- tiplex-PCR assay. J Microbiol Methods. 2010;80:281-6.

50. Douidah L, De Zutter L, Baré J, De Vos $\mathrm{P}$, Vandamme O, Vandenberg $\mathrm{O}$, Van den Abeele AM, Houf K. Occurrence of putative virulence genes in Arcobacter species isolated from humans and animals. J Clin Microbiol. 2012;50(3):735-41.

\section{Publisher's Note}

Springer Nature remains neutral with regard to jurisdictional claims in published maps and institutional affiliations.
Ready to submit your research? Choose BMC and benefit from:

- fast, convenient online submission

- thorough peer review by experienced researchers in your field

- rapid publication on acceptance

- support for research data, including large and complex data types

- gold Open Access which fosters wider collaboration and increased citations

- maximum visibility for your research: over $100 \mathrm{M}$ website views per year

At $\mathrm{BMC}$, research is always in progress.

Learn more biomedcentral.com/submissions 